\title{
A REVISTA LATINO-AMERICANA DE ENFERMAgem INCLUÍdA EM NOVAS BASE DE DADOS INTERNACIONAIS
}

\author{
Maria Helena Palucci Marziale ${ }^{1}$ \\ Isabel Amélia Costa Mendes ${ }^{2}$
}

Ao finalizarmos o ano de 2002 temos a satisfação de informar aos nossos leitores que a Revista LatinoAmericana de Enfermagem passa a integrar a relação de periódicos de mais dois indexadores internacionais: as bases de dados CAB HEALTH e CAB ABSTRACTS.

A CAB HEALTH é uma base de dados especializada em nutrição humana, doenças tropicais parasitárias notificáveis e plantas medicinais. Oferece acesso a resumos da literatura científica mundial desde 1973 com cobertura de periódicos, livros, relatórios de pesquisas, patentes e padrões, teses, anais de congressos, relatórios anuais, informações sobre países em desenvolvimento e outras literaturas de difícil obtenção em inglês e outros idiomas.

A referida base de dados contém mais de 860.000 registros e 45.000 novos registros são incluídos anualmente. Praticamente todas as palavras podem ser pesquisadas, permitindo o fácil acesso a essa importante coleção de referências à literatura relacionada à saúde humana e doença em âmbito internacional. $\mathrm{O}$ acesso à base de dados está disponível em CD ROM e online, sendo necessário o pagamento de taxa.

A CAB ABSTRACTS é uma base bibliográfica de dados compilada pela CABI Publishing. Ela cobre a literatura sobre pesquisas significativas e de desenvolvimento nas áreas de nutrição humana, aspectos sobre a saúde humana, agricultura, floresta, saúde animal e controle e preservação de recursos humanos. Mais de quatro milhões de registros foram incluídos na base de dados desde sua informatização em 1973. Esses registros estão disponíveis através de ampla gama de produtos e serviços nos formatos impresso e eletrônico. $O$ acesso é disponível em CD ROM e online na Biblioteca de Referência Eletrônica (Electronic Reference Library - ERL), com consulta gratuita ao SIBI (Sistema Integrado de Bibliotecas) no endereço www.usp.br/sibi, acesso a base de dados.

Neste número, além dos artigos científicos a revista traz os índices das publicações de 2002 e a nominata dos consultores que no ano de 2002 auxiliaram a Comissão de Editoração a publicar artigos de qualidade, de pesquisadores do Brasil e do exterior, permitindo a divulgação da produção do conhecimento produzido pela Enfermagem e áreas afins.

Agradecemos a contribuição dos consultores pelo trabalho realizado, aos pesquisadores por elegerem esta revista para divulgar seus artigos, nossos leitores por estarem conosco, ao CNPq e a FAPESP pelo financiamento recebido e a toda equipe de profissionais que com dedicação tem possibilitado fazer deste um dos melhores veículos de divulgação da Enfermagem latinoamericana.

Editores da Revista Latino-Americana de Enfermagem da Escola de Enfermagem de Ribeirão Preto, da Universidade de São Paulo, Centro Colaborador da OMS para o desenvolvimento da pesquisa em enfermagem: ${ }^{1}$ Professor Livre-Docente, e-mail: marziale@eerp.usp.br; ${ }^{2}$ Professor Titular, e-mail: iamendes@eerp.usp.br 


\title{
THE REVISTA LATINO-AMERICANA DE ENFERMAGEM INDEXED IN NEW INTERNATIONAL DATABASES
}

\author{
Maria Helena Palucci Marziale ${ }^{1}$ \\ Isabel Amélia Costa Mendes ${ }^{2}$
}

We are finishing 2002 and are pleased to inform to our readers that the Revista Latino-Americana de Enfermagem is now also indexed in two international databases: CAB HEALTH and CAB ABSTRACTS.

CAB HEALTH $囚$ is a database specialized in human nutrition, parasitic, communicable and tropical diseases and medicinal plants. It provides access to abstracts of the world's research literature from 1973 to present with coverage of English and foreign language journals, books, research reports, patents and standards, dissertations, conference proceedings, annual reports, developing country information and other difficult to obtain literature. The database contains over 860,000 records with 45,000 records added annually. Virtually every word is searchable, allowing for easy access to this important collection of references to international human health and diseases literature. The entire database is available on a CDROM and online and requires the payment of a fee.

CAB ABSTRACTS $\otimes$ is a bibliographic database compiled by CABI Publishing. It covers the significant research and development literature in the fields of agriculture, forestry, aspects of human health, human nutrition, animal health and the management and conservation of natural resources. Over four million records have been added to the database since its computerization in 1973. These records are made available through a wide range of products and services both printed and electronic. The database is available on a CDROM and online at the Electronic Reference Library - ERL), that can be accessed free of charge through SIBI - www.usp.br/sibi.

In this issue, besides scientific articles, we added the indexes of this Journal 2002 publications and the names of the consultants who assisted the Editorial Board in the publication of articles characterized by their quality, enabling the dissemination of the knowledge produced by Nursing and related fields.

We thank the contribution of these consultants and of the researchers who chose this journal to publish their articles. We would also acknowledge and thank our readers, CNPQ, FAPESP and the staff who have worked with dedication to make this journal one of the most significant dissemination means of the Latin American Nursing production.

Editors of Latin American Journal of Nursing of Ribeirão Preto of the University of São Paulo at Ribeirão Preto College of Nursing - WHO Collaborating Centre for Nursing Research Development: ${ }^{1}$ Associate Professor, e-mail: marziale@eerp.usp.br; ${ }^{2}$ Full Professor, e-mail: iamendes@eerp.usp.br 


\title{
LA REVISTA LATINOAMERICANA DE ENFERMERÍA INCLUIDA EN NUEVAS BASES DE DATOS INTERNACIONALES
}

\author{
Maria Helena Palucci Marziale ${ }^{1}$ \\ Isabel Amélia Costa Mendes²
}

\begin{abstract}
Al finalizar el año 2002 tenemos la satisfacción de informar a nuestros lectores que la Revista Latinoamericana de enfermería para a integrar la relación de revistas de otros dos indexadores internacionales: Las bases de datos $C A B$ HEALTH Y CAB ABSTRACTS.

La CAB HEALTH es una base de datos especializada en nutrición humana, enfermedades tropicales parasitarias notificables y plantas medicinales. Ofrece acceso a resúmenes de la literatura científica mundial desde 1973 con cobertura de revistas, libros, informes de investigación, patentes, tesis, anales de congresos, informes anuales, informaciones sobre países en desarrollo y otras literaturas de difícil obtención en ingles y otros idiomas.

La referida base de datos contiene más de 860.000 registros y 45.000 nuevos registros son incluidos anualmente. Prácticamente todas las palabras pueden ser investigadas permitiendo el fácil acceso a esta importante colección de referencias, a la literatura relacionada con la salud humana y la enfermedad en el ámbito internacional. El acceso a al base de datos está disponible en CD ROM y on-line, siendo necesario el pago por estos servicios.

La CAB ABSTRACTS es una base bibliográfica de datos compilada por la CABI Publishing. Ella cubre la literatura sobre investigaciones significativas y de desarrollo en las áreas de nutrición humana, aspectos sobre la salud humana, agricultura, floresta, salud animal y control y preservación de recursos humanos. Más de cuatro millones de registros fueron incluidos en la base de datos desde su informatización en 1973. Estos registros están disponibles a través de una amplia gama de productos y servicios en los formatos impreso y electrónico. El acceso en CD-ROM u online puede hacerse a través de la Biblioteca de Referencia Electrónica (Electronic Reference Library - ERL), o consultando gratuitamente en el SIBI (Sistema Integrado de Bibliotecas) en la direccion www.usp.br/sibi, acesso a base de datos.

En este numero, además de los artículos científicos, la revista trae los índices de las publicaciones del 2002 y la nominación de los consultores que en el año del 2002 ayudaron a la comision consultora a publicar artículos de calidad, de investigadores del Brasil y del exterior, permitiendo la divulgación de la producción de conocimiento producido por la enfermería y áreas afines.

Agradecemos la contribución de los consultores por el trabajo realizado, a los investigadores por elegir esta revista para divulgar sus artículos, a nuestros lectores por estar con nosotros, al CNPq y a FAPESP por el financiamiento recibido y a todo el equipo de profesionales que con dedicación han facilitado hacer de este uno de los mejores vehiculos de divulgación de la Enfermería Latinoamericana.
\end{abstract}

Editores de la Revista Latinoamericana de Enfermería de la Escuela de Enfermería de Ribeirão Preto de la Universidad de São Paulo, Centro Colaborador de la OMS para el desarrollo de la investigación en enfermería: ${ }^{1}$ Professor Libre-Docente, correo electrónico: marziale@eerp.usp.br;

2 Professor Titular, correo electrónico: iamendes@eerp.usp.br 
